\title{
NO-SOLICITATION AND NO-DISTRIBUTION RULES: PRESUMPTIVE VALIDITY AND DISCRIMINATION
}

Unions may use various methods in an attempt to organize employees, including oral solicitation and distribution of printed material on company property. The employer may prohibit all solicitation and distribution by employee or nonemployee organizers, or the prohibition may be absolute as to nonemployees and limited as to employees. The permissible scope of the restrictions may vary as to whether the parties are on their working time or not, or whether they are in a working or nonworking area. Moreover, different standards may apply as to solicitation as opposed to distribution rules.

Under section 8(a)(1) of the Labor Management Relations Act, ${ }^{1}$ an employer may not "interfere with, restrain, or coerce employees in the exercise" of their "right to self-organization, to form, join, or assist labor organizations ...."2 Since the above-described rules may restrict organizational efforts, they must be reconciled with this statutory command.

Although the section 8(a) (1) prohibition of employer interference with employee organization restricts the employer's formerly unrestricted power to forbid all solicitation and distribution on his property, it is clear that it cannot be read as a total abrogation of his right to regulate the conduct of both employees and nonemployees. ${ }^{3}$ Consequently, in determining the validity of no-solicitation and no-distribution rules, consideration must be given to the employer's right to prevent anticipated or actual interference with business efficiency and production. In balancing these factors, the Board, ${ }^{4}$ with court approval, ${ }^{5}$ rejected a case-by-case approach in this area and instead established presumptions of validity ${ }^{6}$ and invalidity ${ }^{7}$ of no-solicitation and no-distribution rules depending upon the

161 Stat. 140 (1947), 29 U.S.C. \$158(a) (1) (1958) [hereinafter referred to as "the Act"]. (1958).

2 Labor Management Relations Act §7, 61 Stat. 140 (1947), 29 U.S.C. § 157

3 See NLRB v. United Steelworkers, 357 U.S. 357, 361-64 (1958); NLRB v. Babcock \& Wilcox Co., 351 U.S. 105, 112 (1956); Republic Aviation Corp. v. NLRB, 324 U.S. 793 (1945).

${ }_{4}$ See, e.g., Maxam Buffalo, Inc., 139 N.L.R.B. 1040 (1962); Walton Mfg. Co., 126 N.L.R.B. 697 (1960), enforced, 289 F.2d 177 (5th Cir. 1961) ; Peyton Packing Co., 49 N.L.R.B. 828 (1943), enforced, 142 F.2d 1009 (5th Cir.), cert. denied, 323 U.S. 730 (1944).

5 NLRB v. United Steelworkers, 357 U.S. 357 (1958); NLRB v. Babcock \& Wilcox Co., 351 U.S. 105 (1956); Republic Aviation Corp. v. NLRB, 324 U.S. 793 (1945); NLRB v. Rockwell Mfg. Co., 271 F.2d 109 (3d Cir. 1959); NLRB v. Murphy Diesel Co., 263 F.2d 301 (7th Cir. 1959).

6 Star-Brite Indus., Inc., 127 N.L.R.B. 1008 (1960); Hot Point Co., 120 N.L.R.B. 1768 (1958); Pacemaker Corp., 120 N.L.R.B. 987 (1958); Atlas Boot Mfg. Co., 116 N.L.R.B. 565 (1956) ; Dixie Furniture Co., 101 N.L.R.B. 1295 (1952); Dallas Tank \& Welding Co., 51 N.L.R.B. 1315 (1943).

7 Minneapolis-Honeywell Regulator Co., 139 N.L.R.B. 849 (1962) ; Young Spring \& Wire Corp., 138 N.L.R.B. 643 (1962); Stoddard-Quirk Mfg. Co., 138 N.L.R.B. 615 (1962); American Screen Prods. Co., 138 N.L.R.B. 87 (1962); Texas Aluminum 
scope of the restriction. Two approaches can be discerned for deciding which presumptions should be established and the kind of evidence necessary to overcome them. For convenience, they may be termed the "harm-to-the-employees" and the "need-of-the-employer" approaches. Both recognize the need for a balancing of the conflicting rights of employer and employees, but each starts at a different pole, assigns different weights to the relevant factors, and often produces opposite conclusions.

Underlying the "harm-to-the-employees" approach is the analysis that prior to the enactment of section 8 (a) (1), an employer could lawfully prohibit all organizational activities on his property $;^{8}$ section $8(a)(1)$ was intended to limit this right only to the extent necessary to enable the employees to organize. Consequently, an employer should be permitted to prohibit such activity unless the employees can show significant harm to their organizational efforts. Moreover, an employer should be permitted to rebut any presumption of invalidity by showing that his particular restriction does not cause significant harm to the employees because reasonable alternatives are available. However, this approach completely ignores the employer's discriminatory motive and also seems to ignore the underlying policy of the Labor Management Relations Act of encouraging employee organization. ${ }^{9}$

Under the "need-of-the-employer" approach, section $8(a)(1)$ is interpreted as a repudiation of the theory that an employer's property rights alone justify restriction of employee organizational activities; such restriction is unlawful if it has no business justification, regardless of its effect on the employees' organizational effort. Any restriction of organizational solicitation and distribution is considered unlawful absent proof or a rational basis for presuming that the particular restriction is necessary to prevent anticipated or actual interference with business efficiency and production. This remedies the deficiencies of the "harm-to-the-employees" approach by demonstrating concern for the employer's motive.

\section{Working Time Rules}

The Board has consistently declared that no-solicitation and nodistribution ${ }^{10}$ rules are presumptively valid insofar as applicable only dur-

Co., 131 N.L.R.B. 443 (1961), enforced, 300 F.2d 315 (5th Cir. 1962) ; Linda Jo Shoe Co., 129 N.L.R.B. 179, 184-85 (1960), enforced, 307 F.2d 355 (5th Cir. 1962); Meier \& Frank Co., 89 N.L.R.B. 1016, 1017 (1950); Peyton Packing Co., 49 N.L'. R.B. 828, 843-44 (1943), enforced, 142 F.2d 1009 (5th Cir.), cert. denied, 323 U.S. 730 (1944).

8 See United Steelworkers v. NLRB, 243 F.2d 593, 597 (D.C. Cir. 1956), rev'd on other grounds, 357 U.S. 357 (1958).

9 Cf. NLRB v. Erie Resistor Corp., 373 U.S. 221 (1963) ; NLRB v. Jones \& Laughlin Steel Corp., 301 U.S. 1 (1937). For a legislative statement of this policy, see 61 Stat. 136 (1947), 29 U.S.C. §141(b) (1958); 61 Stat. 136-37 (1947), 29 U.S.C. § 151 (1958).

10 The rule need not be enforced to be invalid since mere promulgation may have a deterrent effect on the employees' organizational activity. See NLRB v. Great 
ing the employees' working time. ${ }^{11}$ This presumption is consistent with a "need-of-the-employer" approach since in most instances such bans will be motivated by the employer's desire to prevent business interference caused by such organizational activity.

The person who is the object of solicitation or distribution is 'usually distracted from his work, though such distraction and its impact on business production may vary according to the type of business involved. ${ }^{12}$ Since it is reasonable to presume that working time solicitation and distribution bans are motivated by a valid business interest, it is proper to place the burden of establishing discriminatory motive or enforcement upon the challenging party. The definition of "working time" in this context is practical and flexible ${ }^{13}$ in that it does not include the entire workday; ${ }^{14}$ an employee is not on his working time during lunch ${ }^{15}$ or similar rest periods. ${ }^{16}$ The test seems to be whether he is performing his functions as an employee at that time.

Atl. \& Pac. Tea Co., 277 F.2d 759 (5th Cir. 1960) ; Rutter-Rex Mfg. Co., 86 N.L.R.B. 470 (1949); Allen-Morrison Sign Co., 79 N.L.R.B. 904, 906 (1948); cf. NLRB v. Glenn L. Martin-Neb. Co., 141 F. 2d 371 (8th Cir. 1944). This fact has sometimes been ignored. See Wah Chang Corp. v. NLRB, 305 F.2d 15 (9th Cir. 1962); NLRB v. Keystone Steel \& Wire Co., 155 F.2d 553 (7th Cir. 1946).

11 NLRB v. W. T. Grant Co., 315 F.2d 83 (9th Cir. 1963) ; NLRB v. Empire Mfg. Corp., 260 F.2d 528 (4th Cir. 1958) ; Olin Indus., Inc. v. NLRB, 191 F.2d 613 (5th Cir. 1951), cert. denied, 343 U.S. 919 (1952); NLRB v, Montgomery Ward \& Co., 157 F.2d 486, 493-94 (8th Cir. 1946) ; NLRB v. Edinburg Citrus Ass'n, 147 F.2d 353 (5th Cir. 1945); Valley Feed \& Supply Co., 135 N.L.R.B. 778, 793 (1962); Georgia-Pac. Corp., 132 N.L.R.B. 612, 615-16 (1961) ; Midwestern Instruments, Inc., 131 N.L.R.B. 1026 (1961) ; Laub Baking Co., 131 N.L.R.B. 869 (1961); Delta Finishing Co., 111 N.L.R.B. 659, 661 (1955) ; Republic Aviation Corp., 51 N.L.R.B. 1186, 1187 (1943), enforced, 142 F.2d 193 (2d Cir. 1944), aff'd, 324 U.S. 793 (1945) ; Peyton Packing Co., 49 N.L.R.B. 828, 843-44 (1943), enforced, 142 F.2d 1009 (5th Cir.), cert. dexied, 323 U.S. 730 (1944).

12 For example, protracted solicitation may have an insignificant impact on the efficiency of a truck driver who is being solicited by his alternate in the cab. The legality of banning such solicitation, even though the employees are on their working time, is doubtful because of the tenuous connection between the ban and a legitimate business need; cf. NLRB v. Floridan Hotel, Inc., 318 F.2d 545 (5th Cir. 1963) (absent special circumstances, employer may not ban employee wearing of union buttons); NLRB y. Power Equip. Co., 313 F.2d 438 (6th Cir. 1963) (union inscribed shirts); Bilton Insulation, Inc. v. NLRB, 297 F.2d 141 (4th Cir. 1961) (union buttons); Kimble Glass Co. v. NLRB, 230 F.2d 484 (6th Cir. 1956) (union badges). An employer demonstration of serious business need may justify prohibitions of union button wearing. See Caterpillar Tractor Co. v. NLRB, 230 F.2d 357 (7th Cir. 1956); Boeing Airplane Co. v. NLRB, 217 F.2d 369 (9th Cir. 1954). Even a brief solicitation or distribution may have a serious impact on the efficiency of assemblyline employees. See Peyton Packing Co., 49 N.L.R.B. 828, 843-44 (1943), enforced, 142 F.2d 1009 (5th Cir.), cert. denied, 323 U.S. 730 (1944).

13 See, e.g., NLRB v. Armstrong Tire \& Rubber Co., 262 F.2d 812 (5th Cir. 1959) ; Midland Mfg. Co., 134 N.L.R.B. 10 (1961).

14 See NLRB y. Monarch Tool Co., 210 F.2d 183 (6th Cir.), cert. denied, 347 U.S. 967 (1954); Williamson-Dickie Mfg. Co., 115 N.L.R.B. 356, 363 (1956); cf. Florida Sugar Corp., 142 N.L.R.B. No. 57, 53 L.R.R.M. 1060 (1963); Cal-Style Furniture Mfg. Co., 141 N.L.R.B. No. 45, 52 L.R.R.M. 1368 (1963).

15 Olin Indus., Inc., 191 F.2d 613 (5th Cir. 1951), cert. denied, 343 U.S. 919 (1952) ; I. F. Sales Co., 82 N.L.R.B. 137 (1949).

16 See, e.g., NLRB v. Armstrong Tire \& Rubber Co., 262 F.2d 812 (5th Cir. 1959) ; NLRB v. Essex Wire Corp., 245 F.2d 589 (9th Cir. 1957) ; NLRB v. Monarch Tool Co., 210 F.2d 183, 187 (6th Cir.), cert. denied, 347 U.S. 967 (1954). 


\section{Nonworking Time Rules}

\section{A. No-Solicitation Rules}

Rules prohibiting employee solicitation during the nonworking time of both the soliciting and solicited employees, whether in working or nonworking areas, are invalid ${ }^{17}$ unless the employer can show special circumstances-that because of the peculiar nature of his business, nonworking time solicitation is disruptive of the efficiency of the business. ${ }^{18}$ Again, the Board has adopted a pure "need-of-the-employer" approach, reasoning that in most cases restrictions of employee solicitation during nonworking time are not justified by any legitimate business purpose. It is therefore reasonable to presume that the restriction is invalid either because it is designed to frustrate employee organizational efforts, or because it constitutes unwarranted interference with such efforts. ${ }^{19}$ Moreover, an employer's demonstration of a lack of discriminatory purpose will not overcome this presumption. Absent a showing of special circumstances, the restriction is conclusively presumed to be unlawful insofar as applicable to nonworking time solicitation, regardless of its impact on the employees' organizational ability, since lack of "harm-to-the-employees" cannot validate such a broad solicitation ban. ${ }^{20}$

\section{B. No-Distribution Rules}

In contrast to the Board's consistent treatment of no-solicitation rules, nonworking time no-distribution rules "have had a checkered history." 21 In early cases the Board held that a mere employer assertion of a litter-prevention motive would justify a prohibition of all distribution

17 Minneapolis-Honeywell Regulator Co., 139 N.L.R.B. 849 (1962) ; Republic Aviation Corp., 51 N.L.R.B. 1186, 1187 (1943), enforced, 142 F.2d 193 (2d Cir. 1944), aff'd, 324 U.S. 793 (1945); Peyton Packing Co., 49 N.L.R.B. 828, 843-44 (1943), enforced, 142 F.2d 1009 '(5th Cir.), cert. denied, 323 U.S. 730 (1944); Carter Carburetor Corp., 48 N.L.R.B. 354, 355-56 (1943), enforced, 140 F.2d 714 (8th Cir. 1944); United States Cartridge Co., 47 N.L.R.B. 896, 897-98 (1943); Denver Tent \& Awning Co., 47 N.L.R.B. 586, 592-93, enforced, 138 F.2d 410 (10th Cir. 1943). But cf. Midland Steel Prods. Co. v. NLRB, 113 F.2d 800 (6th Cir. 1940). However, because of the peculiar circumstances of the business, retail stores are permitted to ban all solicitation on the selling floors. NLRB v. May Dep't Stores Co., 154 F.2d 533 (8th Cir.), cert. denied, 329 U.S. 725 (1946) ; Marshall Field \& Co. v. NLRB, 200 F.2d 375 (7th Cir. 1952); cf. May Dep't Stores Co. v. NLRB, 316 F.2d 797 (6th Cir. 1963).

18 See Peyton Packing Co., 49 N.L.R.B. 828, 843-44 (1943), enforced, 142 F.2d 1009 (5th Cir.), cert. denied, 323 U.S. 730 (1944).

19 See, e.g., Republic Aviation Corp., 51 N.L.R.B. 1186, 1187 (1943), enforced, 142 F.2d 193 (2d Cir. 1944), aff'd, 324 U.S. 793 (1945); Peyton Packing Co., 49 N.L.R.B. 828 (1943), enforced, 142 F.2d 1009 (5th Cir.), cert. denied, 323 U.S. 730 (1944).

20 Stoddard-Quirk Mfg. Co., 138 N.L.R.B. 615, 622-23 (1962). Compare Republic Aviation Corp. v. NLRB, 324 U.S. 793 (1945), with NLRB v. Babcock \& Wilcox Co., 351 U.S. 105 (1956).

21 United Steelworkers v. NLRB, 243 F.2d 593, 597 (D.C. Cir. 1956), reø'd on other grounds, 357 U.S. 357 (1958). 
on company property, 22 a presumption rebuttable only by showing serious impairment of organizational efforts. ${ }^{23}$ The Board later abandoned this rule and held that a nonworking time distribution ban was invalid, apparently regardless of the plant area affected, absent an employer showing of special circumstances. ${ }^{24}$ However, the Board shortly thereafter overruled these cases $^{25}$ and reestablished the prior rule that working time and nonworking time distribution bans were presumptively valid, but in nonworking areas the extent of lawful restriction remained unclear. ${ }^{26}$ In 1960 the Board again considered this problem in Walton $M f g . \mathrm{Co}^{27}$ and, after reviewing the leading no-solicitation and no-distribution cases, ${ }^{28}$ readopted the pure "need-of-the-employer" approach, holding that a no-distribution rule is presumptively invalid if applicable to nonworking time, whether in working or nonworking areas.

\section{The Stoddard-Quirk Rule}

In 1962 the Board again shifted ground, and in Stoddard-Quirk Mfg. $\mathrm{Co}^{29}$ held, two members dissenting, that although a no-distribution rule is presumptively invalid as applied to nonworking time employee distribution in nonworking areas, it is presumptively valid as applied to even nonworking time distribution in the working areas. In reaching this result the majority maintained that no case ever held that no-solicitation and no-distribution rules should be equated as to presumptive validity.

Although the Board attempted to distinguish $W$ alton, ${ }^{30}$ it is clear that it overruled Walton in part and, more important, rejected the Walton approach to the no-distribution rule issue.

22 See, e.g., Tabin-Picker \& Co., 50 N.L.R.B. 928, 930 (1943).

23 See General Motors Corp., 73 N.L.R.B. 74, 76 (1947); Goodyear Aircraft Corp., 57 N.L.R.B. 502, 508 (1944); cf. North Am. Aviation, Inc., 56 N.L.R.B. 959, 961-62 (1944).

24 See Chicopee Mfg. Corp., 85 N.L.R.B. 1439, 1440 (1949); American BookStratford Press, Inc., 80 N.L.R.B. 914, 915 (1948).

25 See Monolith Portland Cement Co., 94 N.L.R.B. 1358, 1366 (1951) ; cf. Rockwell Mfg. Co., 121 N.L.R.B. 288, 289 (1958), rev'd on other grounds, 271 F.2d 109 (3d Cir. 1959).

26 Delta Finishing Co., 111 N.L.R.B. 659, 661 (1955); Colonial Shirt Corp., 96 N.L.R.B. 711, 713 (1951) ; Monolith Portland Cement Co., 94 N.L.R.B. 1358, 1366 (1951); cf. Nutone, Inc., 112 N.L.R.B. 1153, 1164-65 (1955), modified sub nom. United 'Steelworkers v. NLRB, 243 F.2d 593 (D.C. Cir. 1956), rev'd, 357 U.S. 357 (1958).

27126 N.L.R.B. 697 (1960), enforced, 289 F.2d 177 (5th Cir. 1961).

$28 I d$. at $697-98$. The Board reviewed and concisely stated its interpretation of Republic Aviation Corp. v. NLRB, 324 U.S. 793 (1945), NLRB v. Babcock \& Wilcox Co., 351 U.S. 105 (1956), and NLRB v. United Steelworkers, 357 U.S. 357 (1958).

29138 N.L.R.B. 615 (1962); accord, General Indus. Electronics Co., 138 N.L. R.B. 1371 (1962).

30 The Board distinguished Walton by stating in a footnote that any statements in that case as to nonworking time no-distribution rules were unnecessary to the decision. Stoddard-Quirk Mfg. Co., 138 N.L.R.B. 615, $619 \mathrm{n.5}$ (1962). It is arguable that the Board in Walton could have decided that the employer rule in question violated $\S 8$ (a) (1) because it restricted nonworking time solicitation, see, e.g., Peyton Packing Co., Inc., 49 N.L.R.B. 828, 843-44 (1943), enforced, 142 F.2d 1009 (5th Cir.), cert. denied, 323 U.S. 730 (1944); Carter Carburetor Corp., 48 N.L.R.B. 354, 
In rejecting Walton, the Stoddard-Quirk Board adopted a combination of the "need-of-the-employer" and the "harm-to-the-employees" approaches based upon a premise derived from Republic Aviation Corp. $v$. $N L R B^{31}$ and NLRB v. Babcock \& Wilcox Co. ${ }^{32}$ that the validity of solicitation and distribution bans depends on balancing the legitimate rights of both employer and employees. The Board then proceeded to examine the employer's need for a distribution ban and its impact on the employees' organizational capability.

The Board maintained that, in sharp contrast to the business danger of distracting employees by solicitation, distribution presented an additional littering hazard which it considered sufficient to justify presumptive validity.

The Board found support for its holding in NLRB v. Le Tournean $C_{0}{ }^{33}$ and NLRB v. Babcock \& Wilcox Co. ${ }^{34}$ In Le Tourneau the Court sustained the Board in holding unlawful an employer's ban of employee distribution in the company parking lot. Instead of simply invalidating the rule because of its application to nonworking time, the Board in Le Tourneau $\mathrm{Co}^{35}$ followed its then practice ${ }^{36}$ of examining evidence as to the effect of this restriction upon employee communication and balanced this against the employer's necessity. It is therefore clear that the Board was distinguishing between the presumptive validity of no-solicitation and nodistribution rules. The majority in Stoddard-Quirk maintained that the

355-56 (1943), enforced, 140 F.2d 714 (8th Cir. 1944); United States Cartridge Co., 47 N.L.R.B. 896 (1943) ; Denver Tent \& Awning Co., 47 N.L.R.B. 586, enforced, 138 F.2d 410 (10th Cir. 1943), and was, therefore, not required to consider the validity of the distributional aspects of the rule. It is also arguable that even as to the latter issue the Board could have invalidated the rule insofar as it restricted nonworking time distribution in nonworking areas, see, e.g., NLRB v. Caldwell Furniture Co., 199 F.2d 267 (4th Cir. 1952), cert. denied, 345 U.S. 907 (1953); Ie Tourneau Co., 54 N.L.R.B. 1253, order set aside, 143 F.2d 67 (1944), enforced, 324 U.S. 793 (1945), without deciding its validity as applied to working area distribution. However, such interpretation of Walton ignores the fact that the issue before the Board in that case was the validity of an integrated employer rule prohibiting both solicitation and distribution at any time, anywhere on company property. NLRB v. Walton Mfg. Co., 289 F.2d 177, 179-80 (5th Cir. 1961). Thus the Walton Board stated:

[W] have here a no-solicitation and no-distribution rule applicable to employees during their non-working time, which rule is presumptively invalid, in the absence of evidence that special circumstances make the rule necessary in order to maintain production or discipline. As Respondent introduced no evidence to show such special circumstances, the rule is invalid.

Walton Mfg. Co., 126 N.L.R.B. 697, 699 (1960). Furthermore, it was necessary for the Board to consider all aspects of the rule in order to issue a proper order for rescission of the rule in both its solicitational and distributional aspects to the extent that each was unlawful.

31324 U.S. 793 (1945). This case was decided together with NLRB v. Le

Tourneau Co.

32351 U.S. 105 (1956).

33324 U.S. 793 (1945).

34351 U.S. $105 \cdot(1956)$.

3554 N.L.R.B. 1253, enforcement denied, 143 F.2d 67 (5th Cir. 1944), rev'd, 324 U.S. 793 (1945).

36 See, e.g., Monolith Portland Cement Co., 94 N.L.R.B. 1358 (1951); General Motors Corp., 73 N.L.R.B. 74 (1947); Goodyear Aircraft Corp., 57 N.L.R.B. 502 (1944) ; North Am. Aviation, Inc., 56 N.L.R.B. 959 (1944); Tabin-Picker \& Co., 50 N.L.R.B. 928 (1943). 
Court, in upholding the Board, thereby approved this distinction. However, the Court made no such intimations, but merely determined that the Board's finding was supported by substantial evidence upon the entire record. Consequently, the Board could establish a rule of presumptive invalidity of nonworking time no-distribution rules ${ }^{37}$ without coming in conflict with the Court's holding in Le Tournean.

In Babcock \& Wilcox Co.,38 the Board held invalid a parking lot distribution ban as applied to nonemployee organizers; but the Supreme Court held that an employer may prohibit nonemployee distribution on his property absent a showing that other avenues of contacting the employees outside of company property were inadequate..$^{39}$ Since section $8(a)(1)$ only proscribes interference with employee organizational rights, nonemployees' rights to organize on company property depend upon the effect which denial of access would have on the employees' right to learn from them the advantages of self-organization. It is arguable that the employees' rights are not infringed if reasonable alternatives of contacting them exist. Moreover, employers may reasonably have legitimate business reasons for denying access to nonemployees whose responsibility and honesty are unknown to them. ${ }^{40}$ Nevcrtheless, the opinion may be read broadly to validate a ban on all such nonemployee activity even if the purpose is to forestall organization, as long as reasonable means of communication are available outside company property and the ban is enforced without discrimination against all nonemployee organizers. ${ }^{41}$ Adopting the Babcock \& Wilcox rationale, the Board in Stoddard-Quirk reasoned that while effective solicitation requires adequate time for employee discussion, effective distribution requires only delivery of a printed message. Consequently, restrictions of nonworking time solicitation even in working areas would have a serious impact on employee communication; similar restrictions of distribution would have a less serious impact, since literature may still be delivered to the employees in nonworking areas-for example, at plant gates or in cafeterias. Balancing this absence of serious curtailment of the employees' overall communication capabilities against the littering hazard, the Board held that a broad working area distribution ban was valid.

A serious objection to this reasoning lies in the partial use of the Babcock \& Wilcox "harm-to-the-employees" test for judging restrictions of employee distribution, notwithstanding the Court's statements in Babcock \& Wilcox that this test applied solely to restrictions of nonemployee organ-

37 See Waiton Mfg. Co., 126 N.L.R.B. 697 (1960).

38109 N.L.R.B. 485 (1954), enforcement denied, 222 F.2d 316 (5th Cir. 1955), aff'd, 351 U.S. 105 (1956). Two other cases posing the same issue were also decided by the Court. Ranco, Inc., 109 N.L.R.B. 998 (1954), enforced, 222 F.2d 543 (6th Cir. 1955), rev'd, 351 U.S. 105 (1956) ; Seamprufe, Inc., 109 N.L.R.B. 24 (1954), enforcement denied, 222 F.2d 858 (10th Cir. 1955), aff'd, 351 U.S. 105 (1956).

39 NLRB v. Babcock \& Wilcox Co., 351 U.S. 105 (1956).

40 See NLRB v. Great Atl. \& Pac. Tea Co., 277 F.2d 759, 763-64 (5th Cir. 1960).

41 Cf. NLRB v. Monsanto Chem. Co., 225 F.2d 16 (9th Cir. 1955); Holyoke Cinema Shops, Inc., 139 N.L.R.B. 1321 (1962); Salyer Stay Ready Filter Corp., 136 N.L.R.B. 1210 (1962). 
izational activity, 42 and that considerations of the employer's business needs govern the validity of employee distribution restrictions. ${ }^{43}$ The Board itself in Stoddard-Quirk recognized this principle since it held that a prohibition of employee nonworking time nonworking area distribution is presumptively invalid even if alternate means of employee distribution are available off company property. This undercuts the Board's working area distribution reasoning, since it is difficult to see why the impact on employee organizational efforts is relevant to the validity of working area distribution restrictions and irrelevant to the validity of nonworking area distribution restrictions. Therefore, Babcock \& Wilcox is irrelevant to the validity of employee distribution restriction. ${ }^{44}$

\section{An Alternative: The No-Littering Rule}

Under the "need-of-the-employer" approach, the test of validity of a working area distribution ban should be whether or not the employer needs, or may be rationally presumed to need, the ban to prevent significant interference with business efficiency and production. Hence, the desirability of the Stoddard-Quirk rule should depend upon the validity of the Board's assumption that in most cases working area distribution prohibitions are necessary to prevent significant littering. Even assuming the reality of this alleged littering danger, if there is another effective means of litter prevention, a nonworking time distribution ban, unjustified by business necessity, should be considered unlawful either because the ban was designed to impede employee organization, ${ }^{45}$ or because even absent such a purpose it is an unwarranted interference with employee organizational activity. ${ }^{46}$

One clearly lawful ${ }^{47}$ alternative means of litter prevention, suggested by the dissenters ${ }^{48}$ in Stoddark-Quirk and given short shrift by the majority, ${ }^{49}$ would be a rule prohibiting employee littering by which an

42 "No restriction may be placed on the employees' right to discuss self-organization among themselves, unless the employer can demonstrate that a restriction is necessary to maintain production and discipline." NLRB v. Babcock \& Wilcox Co., 351 U.S. 105, 113 (1956). See generally Note, 65 YALE L.J. 423 (1956).

43 See NLRB v. United Aircraft Corp., 324 F.2d 128 (2d Cir. 1963). Contra, NLRB v. Rockwell Mfg. Co., 271 F.2d $109^{\prime}$ (3d Cir. 1959).

44 See NLRB v. United Aircraft Corp., 324 F.2d 128 (2d Cir. 1963); May Dep't Stores Co. v. NLRB, 316 F.2d 797, 799 (6th Cir. 1963); NLRB v. Lake Superior Lumber Corp., 167 F.2d 147 (6th Cir. 1948).

45 See NLRB v. Fairmont Creamery Co., 143 F.2d 668 (10th Cir. 1944); TimeO-Matic, Inc., 121 N.L.R.B. 179 (1958), enforced, 264 F.2d 96 (7th Cir. 1959); Commercial Controls Corp., 118 N.L.R.B. 1344 (1957), enforced, 258 F.2d 102 (2d Cir. 1958); cf. NLRB v. Essex Wire Corp., 245 F.2d 589 (9th Cir. 1957); Kimble Glass Co. v. NLRB, 230 F.2d 484 (6th Cir. 1956).

46 See, e.g., Time-O-Matic, Inc. v. NLRB, 264 F.2d 96 (7th Cir. 1959); cf. Stewart Hog Ring Co., 131 N.L.R.B. 310 (1961).

47 See United Steelworkers v. NLRB, 243 F.2d 593, 597 (D.C. Cir. 1956), rev'd on other grontinds, 357 U.S. 357 (1958).

48 Stoddard-Quirk Mfg. Co., 138 N.L.R.B. 615, 630 n.24 (1962).

49 Id. at 621 n.7. 
employer notifies all employees that they are subject to disciplinary action if they discard the distributed union literature. Presumably this threat would deter an individual from littering to the same extent as the same penalty would deter him from distributing. Nevertheless, it may be argued that normally there are more employee receivers and hence potential litterers than distributors of union literature and, consequently, the penalty would have to deter more individuals than if tied to a distribution ban. While it is true that mathematically the chances of littering are greater under a no-littering rule, it by no means follows that in most cases such a rule would be ineffective. The right of employees to be free from employer interference in their organizational efforts should not turn on such conjecture but should be restricted only where facts show a need for the protection of a legitimate employer interest.50 If the rule proves ineffective, a subsequent no-distribution rule may be justified. The effect of the $W$ alton rule of presumptive invalidity of nonworking time distribution restrictions was merely to require an employer showing of "special circumstances" to validate a broad distribution ban ${ }^{51}$-that maintenance of production, discipline, or efficiency required a nonworking time distribution restriction..$^{52}$ The Board has had sufficient experience in past solicitation and distribution "special circumstances" cases to determine the factual question of whether there is such a substantial business interference as to justify the restriction..$^{53}$ Thus, a mere anticipated danger of working area littering would not be sufficient any more than a mere anticipated danger of working time employee distraction would justify a working area solicitation ban..$^{54}$ Similarly, the mere possibility of a danger of littering would not justify a nonworking area distribution prohibition even under the Stoddard-Quirk rule.55 Nor would a few instances of littering justify either a working area or nonworking area distribution ban. ${ }^{58}$ Instead, the employer would have to show that

50 See NLRB v. Babcock \& Wilcox Co., 351 U.S. 105, 113 (1956); Jacksonville Motors, Inc., 88 N.L.R.B. 181 (1950).

51 See Republic Aviation Corp. v. NLRB, 324 U.S. 793 (1945); Walton Mfg. Co., 126 N.L.R.B. 697 (1960), enforced, 289 F.2d 177 (5th Cir. 1961) ; Peyton Packing Co., 49 N.L.R.B. 828, 843-44 (1943), enforced, 142 F.2d 1009 (5th Cir.), cert. denied, 323 U.S. 730 (1944); cf. NLRB v. Floridan Hotel, Inc., 318 F.2d 545 (5th Cir. 1963).

52 See, e.g., Caterpillar Tractor Co. v. NLRB, 230 F.2d 357 (7th Cir. 1956); Boeing Airplane Co. v. NLRB, 217 F.2d 369 (9th Cir. 1954); cf. May Dep't Stores Co., 59 N.L.R.B. 976 (1944), modified, 154 F.2d 533 (8th Cir.), cert. denied, 329 U.S. 725 (1946).

53 See, e.g., Republic Aviation Corp. v. NLRB, 324 U.S. 793 (1945) ; NLRB v. Floridan Hotel, Inc., 318 F.2d 545 (5th Cir. 1963) ; Boeing Airplane Co. v. NLRB, supra note 52; Jacksonville Motors, Inc., 88 N.L.R.B. 181 (1950); Peyton Packing Co., 49 N.L.R.B. 828, 843-44 (1943), enforced, 142 F.2d 1009 (5th Cir.), cert. denied, 323 U.S. 730 (1944).

$5 \pm$ Stoddard-Quirk Mfg. Co, 138 N.L.R.B. 615 (1962); Minneapolis-Honeywell Regulator Co., 139 N.L.R.B. 849 (1962); Jacksonville Motors, Inc., supra note 53.

5. Republic Aviation Corp. v. NLRB, 324 U.S. 793 (1945) ; Minneapolis-Honeywell Regulator Co., supra note 54.

56 M Iinneapolis-Honeywell Regulator Co., supra note 54; cf. Jacksonville Motors, Inc., 88 N.L.R.B. 181 (1950). 
substantial littering caused interference with production, discipline, or efficiency. ${ }^{57}$

The Board, therefore, should abandon its new Stoddard-Quirk rule and reestablish the $W$ alton rule, allowing the employer to justify a working area distribution ban to prevent littering only after an unsuccessful attempt to enforce a no-littering rule.

\section{Discriminatory Adoption and Enforcement of Presumptively Valid No-Solicitation and No-Distribution RULes}

A presumptively valid no-solicitation or no-distribution rule will be held violative of section 8 (a) (1) if it is shown by the charging party 68 that the rule was promulgated to prevent employee organization rather than for a legitimate business purpose. ${ }^{58}$ Discriminatory enforcement of a presumptively valid rule also violates section 8 (a)(1) ${ }^{60}$ and, if such enforcement results in discharge, suspension, or other alteration of the employment status of a violator, ${ }^{61}$ it also violates section $8(a)(3) .{ }^{62}$ The

57 See, e.g., Republic Aviation Corp. v. NLRB, 324 U.S. 793 (1945) ; NLRB v. United Aircraft Corp., 324 F.2d 128 (2d Cir. 1963).

In rejecting a no-littering rule, the majority in Stoddard-Quirk posed a hypothetical case: where one of two rival distributing factions deliberately discards the other faction's literature in the working area, should both or only one lose its working area distribution privilege? There is no reason why this problem would arise only in working area distribution cases. See, e.g., Minneapolis-Honeywell Regulator Co., 139 N.L.R.B. 849 (1962). Certainly, such a problem would not cause the Board to validate a nonworking area distribution ban, eren if the rule caused no serious impairment of employee organizational efforts. See Republic Aviation Corp. v. NLRB, 324 U.S. 793 (1945) ; Walton Mfg. Co., 126 N.L.R.B. 697 (1960), enforced, 289 F.2d 177 (5th Cir. 1961) ; Peyton Packing Co., 49 N.L.R.B. 828, 843-44 (1943), enforced, 142 F.2d 1009 (5th Cir.), cert. denied, 323 U.S. 730 (1944). In any event, this question can be resolved under the existing "special circumstances" doctrine, which is concerned only with the extent of distribution-caused business interference, and not with the identity of the employees causing the interference, except where they are the employer's agents. Consequently, if sufficient business interference occurs, the employer may prohibit all working area distribution. See Republic Aviation Corp. v. NLRB, supra; Walton Mfg. Co., supra; Peyton Packing Co., supra.

58 The burden of proof is on the General Counsel. See, e.g., Winett, Inc., 135 N.L.R.B. 1305 (1962) ; Continental Aviation \& Eng'r Corp., 125 N.L.R.B. 624 (1959).

59 Revere Camera Co. v. NLRB, 304 F.2d 162 (7th Cir. 1962) ; NLRB v. Fairmont Creamery Co., 143 F.2d 668 (10th Cir. 1944); Carter Carburetor Corp. v. NLRB, 140 F.2d 714 (8th Cir. 1944) ; NLRB v. Denver Tent \& Awning Co., 138 F.2d 410 (10th Cir. 1943) ; Outboard Marine Corp., 142 N.L.R.B. No. 136, 53 L.R.R.M. 1242 (1963); Grand Cent. Aircraft Co., 103 N.L.R.B. 1114 (1953); Stainless Ware Co. of America, 87 N.L.R.B. 138 (1949); Standard-Coosa-Thatcher Co., 85 N.L. R.B. 1358, 1364 (1949); Tomlinson of High Point, Inc., 74 N.L.R.B. 681, 688-89 (1947).

60 See, e.g., NLRB v. Link-Belt Co., 311 U.S. 584 (1941) ; NLRB v. Waterman S.S. Corp., 309 U.S. 206, 224-26 (1940); $c f$. Radio Officers' 'Union v. NLRB, 347 U.S. 17 (1954).

61 NLRB v. May Dep't Stores Co., 154 F.2d 533 (8th Cir. 1946) ; NLRB v. Peyton Packing Co., 142 F.2d 1009 (5th Cir.), cert. denied, 323 U.S. 730 (1944); "M" System, Inc., 123 N.L.R.B. 1281 (1959); William Davies Co., 37 N.L.R.B. 631 (1941), modified, 135 F.2d 179 (7th Cir.), cert. denied, 320 U.S. 770 (1943); of. Story Oldsmobile, Inc., 140 N.L.R.B. 1049 (1963).

6261 Stat. 140-41 (1947), 29 U.S.C. \$158(a) (3) (1958). Enforcement of an invalid rule by discharge or suspension would also violate $\$ 8(a)$ (3). See, e.g., Texas Aluminum Co., 131 N.L.R.B. 443 (1961), enforced, 300 F.2d 315 (5th Cir. 1962). 
question of discrimination in either the adoption or enforcement of a rule is one of fact, ${ }^{63}$ so that the question can be resolved only after an examination of all the relevant facts and circumstances of each case. ${ }^{\text {t4 }}$ A consideration of the principal factors relevant to such a determination is therefore appropriate.

\section{A. Timing of the Adoption or Enforcement of No-Solicitation and No-Distribution Rules}

If an employer, who has either never had ${ }^{65}$ or never seriotsly enforced ${ }^{68}$ a rule against solicitation or distribution, suddenly promulgates such a rule or begins effectively to enforce an existing rule at the start of a union organizational campaign, it is reasonable to infer that his new policy is designed to limit the employees' organizational activity. ${ }^{67}$ It should be questioned, therefore, whether the purpose of this new policy is to prevent anticipated interference with his business efficiency, discipline, and production, or to forestall organization. This is particularly true when prior to the organizational campaign, the employees were allowed to engage in a significant amount of other solicitation or distribution, such as solicitations for charitable organizations, baseball pools, athletic or social organizations, and the like. ${ }^{68}$ However, as the Bcard has made clear, ${ }^{60}$ timing alone cannot be determinative of discriminatory purpose. The employer may justifiably explain lack of prior restriction or enforcement on the ground that in his judgment such activity never posed a serious threat to, or caused any significant actual interference with, his business operations, and that he

63 See, e.g., NLRB v. United Steelworkers, 357 U.S. 357, 362-64 (1958) ; NLRB v. Electric Steam Radiator Corp., 321 F.2d 733 (6th Cir. 1963) ; Star-Brite Indus., Inc., 127 N.L.R.B. 1008, 1010-11 (1960).

64 See, e.g., ibid.; Continental Aviation \& Eng'r Corp., 125 N.L.R.B. 624 (1959); Carolina Mirror Corp., 123 N.L.R.B. 1712 (1959).

65 Time-O-Matic, Inc., 121 N.L.R.B. 179 (1958), enforced, 264 F.2d 96 (7th Cir. 1959); Commercial Controls Corp., 118 N.L.R.B. 1344 (1957), enforced, 258 F.2d 102 (2d Cir. 1959); Standard-Coosa-Thatcher Co., 85 N.L.R.B. 1358, 1364 (1949); William Davies Co., 37 N.L.R.B. 631, 636 (1941), modified, 135 F.2d 179 (7th Cir.), cert. denied, 320 U.S. 770 (1943).

68 Revere Camera Co., 133 N.L.R.B. 1658, 1663 (1961), enforced, 304 F.2d 162 (7th Cir. 1962); Botany Worsted Mills, 4 N.L.R.B. 292, 300-04 (1937), modified, 106 F.2d 263 (3d Cir. 1939).

67 Carolina Mirror Corp., 123 N.L.R.B. 1712 (1959) ; cf. NLRB v. United Steelworkers, 357 U.S. 357 (1958); Armstrong Tire \& Rubber Co., 119 N.L.R.B. 382 (1957), enforced, 262 F.2d 812 (5th Cir. 1959).

68 Ford Radio \& Mica Corp., 115 N.L.R.B. 1046, 1071-72 (1956), enforcement denied on other grounds, 258 F.2d 457 (2d Cir. 1958) ; Standard-Coosa-Thatcher Co., 85 N.L.R.B. 1358, 1364 (1949); Botany Worsted Mills, 4 N.L.R.B. 292, 300-04 (1937), modified, 106 F.2d 263 (3d Cir. 1939).

69 See. e.g., Beiser Aviation Corp., 135 N.L.R.B. 399, 422 (1962) ; Georgia-Pac. Corp., 132 N.L.R.B. 612, 615-16 (1961) ; Midwestern Instruments, Inc., 131 N.L.R.B. 1026 (1961); Laub Baking Co., 131 N.L.R.B. 869, 870 (1961); Star-Brite Indus. Inc., 127 N.L.R.B. 1008, 1010-11 (1960); cf. NLRB v. United Steelworkers, 357 U.S. 357 (1958). 
fears that an organizational campaign now poses such a threat. Moreover, unless the presumption of the validity of no-solicitation and no-distribution rules of limited applicability is to be rendered meaningless, he should not have to prove the business necessity of these rules merely because of the timing of their promulgation or enforcement. However, the charging party is able to prove that the purpose of the rule is to impede the employees' organizational campaign. ${ }^{70}$ While it is true that even a showing of lack of business necessity for the restriction does not ipso facto demonstrate discriminatory purpose since the employer may have believed such necessity existed, the absence of business necessity should be seriously considered by the Board in evaluating the rule's validity. Convincing proof of absence of business necessity should invalidate the restriction as an unwarranted interference with employee organizational activity. ${ }^{71}$

\section{B. Applicability or Enforcement of the Rules Solely to "Union" Solicitation and Distribution}

The clearest case of unlawful discrimination is the promulgation and enforcement of a rule only against solicitation ${ }^{72}$ or distribution ${ }^{73}$ favorable to a particular union, while solicitation or distribution favorable to another union more acceptable to the employer is, with his knowledge, ${ }^{74}$ unrestricted. Similarly unlawful is the restriction of "prounion" solicitation 75

70 NLRB v. Fairmont Creamery Co., 143 F.2d 668 (10th Cir. 1944); Western Corrugated, Inc., 122 N.I.R.B. 1021 (1959); Time-O-Matic, Inc., 121 N.L.R.B. 179 (1958), enforced, 264 F.2d 96 (7th Cir. 1959) ; Star-Brite Indus., Inc., sulpra note 69; Commercial Controls Corp., 118 N.I.R.B. 1344 (1957), enforced, 258 F.2d 102 (2d Cir. 1958); cf. NLRB v. American Compress Warehouse, Inc., 321 F.2d 547 (5th Cir. 1963); NLRB v. Power Equip. Co., 313 F.2d 438 (6th Cir. 1963) ; NLRB v. Essex Wire Corp., 245 F.2d 589 (9th Cir. 1957); Kimble Glass Co., 230 F.2d 484 (6th Cir. 1956); United Aircraft Corp., 134 N.L.R.B. 1632 (1961); Stewart Hog Ring Co., 131 N.L.R.B. 310 (1961).

11 See Time-O-Matic, Inc. v. NLRB, 264 F.2d 96, 101-02 (7th Cir. 1959).

72 NLRB v. Link-Belt Co., 311 U.S. 584 (1941); NLRB v. Waterman S.S. Corp., 309 U.S. 206 (1940) ; NLRB v. Gallup Am. Coal Co., 131 F.2d 665 (10th Cir. 1942); NLRB v. Bersted Mfg. Co., 124 F.2d 409 (6th Cir.), amended, 128 F.2d 738 (6th Cir. 1942) ; American-West African Lines, Inc., 21 N.L.R.B. 691 (1940); cf. Radio Officers' Union v. NLRB, 347 U.S. 17 (1954); International Ass'n of Machinists v. NLRB, 311 U.S. 72, 78 (1940); NLRB v. Essex Wire Corp., 245 F.2d 589 (9th Cir. 1957).

73 See, e.g., NLRB v. Essex Wire Corp., stspra note 72; Carter Carburetor Corp. v. NLRB, 140 F.2d 714 (8th Cir. 1944); cf. Local 357, Teamsters Union v. NLRB, 365 U.S. 667 (1961); International Ass'n of Machinists v. NLRB, supra note 72 .

74 See, e.g., Holyoke Cinema Shops, Inc., 139 N.L.R.B. 1321 (1962) ; Ford Radio \& Mica Corp., 115 N.L.R.B. 1046, 1071 (1956), enforcement denied on other grounds, 258 F.2d 457 (2d Cir. 1958) ; Airfan Radio Corp., 111 N.L.R.B. 566 (1955).

75 Revere Camera Co., 133 N.L.R.B. 1658, 1663-65 (1961), enforced, 304 F.2d 162 (7th Cir. 1962); Franchester Corp., 110 N.L.R.B. 1391 (1954) ; Grand Cent. Aircraft Co., 103 N.L.R.B. 1114, 1127-31, $1147-49$ (1953), enforced,'216 F.2d 572 (9th Cir. 1954) (per curiam); Cherry Rivet Co., 97 N.L.R.B. 1303 (1952) ; Editorial "El Imparcial", Inc., 92 N.L.R.B. 1795, 1796 (1951); Botany Worsted Mills, 4 N.L.R.B. 292, 300-04 (1937), modified, 106 F.2d 263 (3d Cir. 1939). 
and distribution ${ }^{76}$ while the employer knowingly ${ }^{77}$ permits "antiunion" solicitation and distribution. Such patent discrimination not only constitutes an interference with the employees' free choice, but also indicates that the purpose of the restrictions is to impede organization rather than to attain a legitimate business end.

Another factor relevant to discriminatory motive is the fact that the employer's no-solicitation or no-distribution rule is enforced only against union-oriented solicitation and distribution, while other forms of "outside" solicitation and distribution are not restricted. 78 If this other "outside" but nonunion solicitation or distribution is carried on to a significant degree in terms of the number of employees affected, or the amount of working time lost, it may indicate that the restrictions are not imposed to protect any legitimate employer interest but are primarily designied to hamper the organizational effort. ${ }^{79}$ This conclusion is not inevitable since the employer as a matter of business judgment may have decided that he carinot allow any increase in such activity, and that he will forbid union-oriented activity because such activity is potentially more emotional and dangerdus in its effect on employee discipline, efficiency, and production. ${ }^{80}$ However, since it may be no inore emotional or dangerous than some other "outside" forms of activity, the employer's selection may be some indication that he is concerried more with the content of the information being imparted than with the effect on production. Therefore, application solely to union-oriented solicitation and distribution is a relevant factor which rilust be weighed along with other indicators of employer discriminatory intent, stuch as his prior history of antiunion animus.

\section{The Employer's "Violation" of His Own No-Solicitation and No-Distribution Rules}

A question of discriminatory motive arises when an employer, who enforces a presumptively valid no-solicitation or no-distribution rule, "violates" his own rule by engaging in noncoercive but antiunion solicitation during his employees' working time, or by distributing noncoercive but antiunion literature in the wotking area, and refuses an employee request

76 NLRB v. American Furnace Co., 158 F.2d 376 (7th Cir. 1946); William Davies Co., 135 F.2d 179, 181 (7th Cir.), cert. denied, 320 U.S. 770 (1943) ; Time-OMatic, Inc., 121 N.L.R.B. 179 (1958), enforced, 264 F.2d 96 (7th Cir. 1959) ; Odenbach Shipbuilding Corp., 64 N.L.R.B. 1026 (1945).

77 See, e.g., NLRB v. W. T. Grant Co., 315 F.2d 83 (9th Cir. 1963) ; cf. Great Atl. \& Pac. Tea Co., 97 N.I.R.B. 295 (1951); H. \& H. Mfg. Co., 87 N.L.R.B. 1373, 1375 (1949); Merrimac Hat Corp., 85 N.L.R.B. 329, 331 (1949).

78 NLRB v. Gallup Am. Coal Co., 131 F.2d 665 (10th Cir. 1942) ; Revere Camera Co., 133 N.I.R.B. 1658, 1663 (1961), enforced, 304 F.2d 162 (7th Cir. 1962); Ford Radio \& Mica Corp., 115 N.L.R.B. 1046, 1071 (1956), enforcement denied on other grounds, 258 F.2d 457 (2d Cir. 1958); Stainless Ware Co. of America, 87 N.L.R.B. 138, 175 (1949) ; Standard-Coosa-Thatcher Co., 85 N.L.R.B. 1358, 1364-65 (1949); cf. Livingston Shirt Corp., 107 N.L.R.B. 400, 405 (1953).

79 Revere Camera Co., stpra note 78, at 1665; Standard-Coosa-Thatcher Co., supra note 78, at $1364-65$.

80 See Star-Brite Indus., Inc., 127 N.L.R.B. 1008, 1010-11 (1960) ; Bludworth Constr. Co., 123 N.L.R.B. 385, 387 (1959); Pacemaker Corp., 120 N.L.R.B. 987, 989, enforced, 260 F.2d 880 (7th Cir. 1958). 
for equal time. ${ }^{81}$ Although it is arguable that it is a part of the management's prerogative ${ }^{82}$ for an employer to enforce rules governing the employees' activities during working time while not binding himself by the same rules, such a policy still could constitute discrimination against the employees' union activity. The employer's solicitation of employees during their working time, or distribution of antiunion literature in the working area, interferes to some extent with the production and efficiency of his business and creates a danger of littering. Therefore, his actions may indicate that his enforcement of the rules is primarily designed to impede the flow of organizational information ${ }^{83}$ or that there is no real business necessity for the restrictions, ${ }^{84}$ rendering them unwarranted interferences with organizational rights.

However, where only the employer solicits or distributes, he is nevertheless able to control the amount of solicitation or distribution and the extent of its interference with production and cleanliness; that control is lost or at least attenuated when his employees solicit or distribute. Consequently, the employer's enforcement of his no-solicitation or no-distribution rules, at the same time as he "violates" these rules, may be justified by his desire to maintain control over the extent of interference with his business.

A further argument for the validity of the employer's enforcement of his rules, even though he "violates" them, is based upon the so-called employer free speech provisions of section 8(c) of the Act, ${ }^{85}$ which state that an employer may lawfully express, orally or in written or printed form, his views, arguments, or opinions to his employees regarding organizational matters, unless such expression contains a threat of reprisal, force, or promise of benefit. It has been argued ${ }^{86}$ that if an employer must lift his presumptively valid restrictions on employee solicitation or distribution, a condition not contained in the statute would be added to this right of expression. Although it has been argued that employer enforcement of rules against employees is distinguishable from the validity of the employer's expression of his views, ${ }^{87}$ a price is placed upon his section 8 (c) rights if he may not enforce these rules when he engages in such protected expression. ${ }^{88}$

81 See NLRB v. United Steelworkers, 357 U.S. 357, 363 (1958).

82 Nutone, Inc., 112 N.L.R.B. 1153, $1154-55$ (1955), modified, 243 F.2d 593 (D.C. Cir. 1956), rev'd, 357 U.S. 357 (1958).

83 See United Steelworkers v. NLRB, 243 F.2d 593 (D.C. Cir. 1956), rev'd, 357 U.S. 357 (1958).

84 Id. at $598-99$.

8561 Stat. 142 (1947), 29 U.S.C. $\$ 158$ (c) (1958).

86 See, e.g., NLRB v. F. W. Woolworth Co., 214 F.2d 78 (6th Cir. 1954); Bonwit Teller, Inc., 96 N.L.R.B. $608,616-19$ (195i) (dissenting opinion), modified, 197 F.2d 640, 646 '(2d Cir. 1952) (dissenting opinion), cert. denied, 345 U.S. 905 (1953).

87 United Steelworkers v. NLRB, 243 F.2d 593, 599-600 (D.C. Cir. 1956), rev'd, 357 U.S. 357 (1958); Livingston Shirt Corp., 107 N.L.R.B. 400, 410-27 (1953) (dissenting opinion); Bonwit Teller, Inc. v. NLRB, supra note 86, at 614-15.

88 Livingston Shirt Corp., 107 N.L.R.B. 400, 405-06 (1953) ; Bonwit Teller, Inc., supra note 86 , at $616-19$. 
The Supreme Court directly faced this issue in the leading case of NLRB v. United Steelworkers. ${ }^{89}$ The Court clearly rejected an expansive interpretation of section 8 (c) of the Act, considering immaterial ${ }^{00}$ the fact that in one of the cases under review the employer's solicitational activities were coercive ${ }^{91}$ and, hence, unprotected by section $8(\mathrm{c})$, while in the companion case, the employer had only engaged in clearly protected noncoercive solicitation. ${ }^{92}$ The Court held that before the Board may find that an employer who solicits or distributes in "violation" of his own rules commits an unfair labor practice by continuing to enforce these presumptively valid rules, it must find that continued enforcement creates a serious imbalance in the employees' opportunities to counteract the effect of the employer's antiunion solicitation or distribution. ${ }^{93}$ The question arises as to whether this rationale establishes a prerequisite to proof of invalidity of a rule that it create a serious communicational imbalance between employer and employees even where the employer's "violations" of the rule are not a basis for the charge of invalidity. The few cases directly facing this issue are in conflict. In NLRB v. Rockwell Mfg. Co. ${ }^{94}$ the Third Circuit held that under Steelworkers the Board, in deciding whether special circumstances justify a presumptively invalid no-distribution rule, must consider not only evidence of the employer's business need, but also of the effect on the employees' organizational ability, and stated that the necessary quantum of evidence of business need varies inversely with the rule's impact on the employees' organizational effort. However, in Time-O-Matic, Inc. $v$. $N L R B{ }^{95}$ the Seventh Circuit, in approving the Board's invalidation of a no-distribution rule as discriminatorily motivated, limited United Steelworkers to its facts. ${ }^{96}$ A similar view has recently been expressed by the Second Circuit in sustaining the Board's invalidation of a distribution ban in a nonworking area. ${ }^{97}$

A thread common to these cases and United Steelworkers is that in each the employer was enforcing a ban on nonworking time employee distribution in nonworking areas. However, whereas in the cases before the Second, Third, and Seventh Circuits the rule was attacked as invalid on its face, the Court in Steelworkers did not pass upon the rule's per se validity

89357 U.S. 357 (1958).

$80 I d$. at 358,362 .

91 Avondale Mills, 115 N.L.R.B. 840 (1956), enforcement denied, 242 F.2d 669 (5th Cir. 1957), aff'd, 357 U.S. 357 (1958).

Another possible explanation of the Court's rejection of the broader reading of $\$ 8(\mathrm{c})$ may have been a desire to allow the Board flexibility in striking down presumptively valid no-solicitation and no-distribution rules where a serious communicational imbalance is caused by the employer's "violation" even though these "violations" in themselves are protected by $\$ 8(\mathrm{c})$.

92 Nutone, Inc., 112 N.L.R.B. 1153 (1955), modified, 243 F.2d 593 (D.C. Cir. 1956), rev'd, 357 U..S. 357 (1958).

83357 U.S. at $363-64$.

04271 F.2d 109 (3d Cir. 1959).

95264 F.2d 96 (7th Cir. 1959).

96 Time-O-Matic, Inc. v. NLRB, 264 F.2d 96, 100-01 (7th Cir. 1959).

97 NLRB v. United Aircraft Corp., 324 F.2d 128, 131-32 (2d Cir. 1963). 
since this was conceded by all concerned. Indeed, the Court clearly identified the only issue before it:

The very narrow and almost abstract question here derives from the claim that, when the employer himself engages in anti-union solicitation that if engaged in by employees would constitute a violation of the rule . . . his enforcement of an otherwise valid no-solicitation rule against the employees is itself an unfair labor practice. ${ }^{98}$

In answering this question the Court rejected the theory of the Board and the court of appeals that the employer's failure to "obey" his own rule while enforcing it against his employees constituted discriminatory enforcement of the rule, thereby removing the issue of discrimination from the case. Consequently, the Court held that if a no-solicitation or no-distribution rule is "otherwise valid" and is not discriminatorily enforced, its enforcement may not be held unlawful absent a showing of serious harm to the employees' communicational ability.

The only support for the broader reading of the Steelworkers opinion lies in the Court's statement that a showing that the rules "truly diminished the ability of the labor organizations involved to carry their messages to the employees" is "a vital consideration in determining the validity of a nosolicitation rule . . ." 99 In support thereof, the Court cited portions of Republic Aviation Corp. and Babcock \& Wilcox Co. which cast this dictum as merely a restatement of prior law..$^{100}$ Moreover, since the showing of harm to the organizational effort required by Steelworkers is substantially the same as that required by Babcock \& Wilcox, a broad reading of this dictum would require the conclusion that the Court in Steelworkers intended to overrule the previously established distinction between employee and nonemployee solicitation and distribution. A ruling of such breadth should not be so lightly inferred from dictum given the Court's own statement as to the narrow issue decided. The Steelworkers opinion should be read merely as settling the longstanding dispute ${ }^{101}$ as to whether or not the employer who solicits or distributes in "violation" of his rules must allow employees an equal opportunity to reply to his antiunion messages. ${ }^{102}$

98 NLRB v. United Steelworkers, 357 U.S. 357, 362 (1958).

99 Id. at 363 .

100 The portion of the Republic Aviation opinion cited merely indicates that in establishing presumptions of validity or invalidity of these rules the Board should balance the need of the employer and harm to the employee's organizational activities. Republic Aviation Corp. v. NLRB, 324 U.S. 793, 797-98 (1945). The portion of the $B a b c o c k$ \& Wilcox opinion cited indicates the special consideration to be given to the harm to organizational efforts in the case of a ban on nonemployee solicitation and distribution. NLRB v. Babcock \& Wilcox, 351 U.S. 105, 112 (1956).

101 See generally Wollett \& Rowen, Employer Speech and Related Issues, 16 Онго Sr. L.J. 380, 387-95 (1955) ; Note, 43 GEo. L. Rev. 405 (1955); Note, 38 VA. L. REv. 1037 (1952).

102 Compare Bonwit Teller, Inc. v. NLRB, 197 F.2d 640 (2d Cir. 1952), cert. denied, 345 U.S. 905 (1953), with NLRB v. United Steelworkers, 357 U.S. 357 (1958), and May Dep't Stores Co. v. NLRB, 316 F.2d 797 (6th Cir. 1963). 
So read, the Steelworkers case would allow the Board to find unlawful a discriminatory motive from a solicitation or distribution ban after a consideration of all the facts and circumstances, even though the restriction does not create a serious communicational imbalance between employer and employees. Moreover, the Board would remain free to consider the employer "violation" of his own rules as relevant to this factual finding. In the final analysis the ultimate responsibility for making this factual determination should rest on the Board. ${ }^{103}$

John V. Murray

103 The difficulty of finding discrimination in the promulgation or enforcement of these rules raises the question of whether the Board should attempt to find a subjective intent to discriminate or an inference of employer discrimation by an objective appraisal of all the circumstances, e.g., a pattern of past unfair labor practices. The Board's discussion in Stoddard-Quirk of the impact on employees in relation to the scope of a presumptively valid rule may foreshadow such an objective approach. This approach may be justified on evidentiary grounds; however, the Board should not hesitate to find a subjective intent to discriminate in order to prevent use of communicational restrictions as an employer weapon against collective organization. 